\title{
Universiteit
}

Leiden

The Netherlands

\section{Brexit, the EU-UK Withdrawal Agreement, and global treaty (re-)negotiations \\ Larik, J.}

\section{Citation}

Larik, J. (2020). Brexit, the EU-UK Withdrawal Agreement, and global treaty (re-)negotiations. American Journal Of International Law, 114(3), 443-462. doi:10.1017/ajil.2020.29

Version: $\quad$ Publisher's Version

License:

Licensed under Article 25fa Copyright Act/Law (Amendment Taverne)

Downloaded from: $\quad$ https://hdl.handle.net/1887/3194965

Note: To cite this publication please use the final published version (if applicable). 


\title{
CURRENT DEVELOPMENTS
}

\author{
Brexit, the EU-UK Withdrawal Agreement, and Global Treaty \\ (Re-)Negotiations
}

\author{
By Joris Larik*
}

\section{ABSTRACT}

The withdrawal of the United Kingdom from the European Union has prompted a global recalibration of treaty relations. Due to the Withdrawal Agreement and its transition period, the $U K$ is expanding its international treaty-making powers as it is gradually released from the constraints of EU law. Practice to date shows the creation of many new international legal instruments through which governments have sought to address the novel questions that Brexit raises for the international law of treaties.

In an unprecedented development commonly referred to as "Brexit," on the night from January 31 to February 1, 2020, the United Kingdom (UK) left the European Union (EU). This was the moment the Agreement on the Withdrawal of the United Kingdom of Great Britain and Northern Ireland from the European Union and the European Atomic Energy Community—or simply the "Withdrawal Agreement" —entered into force. ${ }^{1}$ This milestone concluded three-and-a-half years of tensions and difficult negotiations following the June 2016 referendum in the UK, in which a narrow majority voted in favor of leaving the EU after more than four decades of membership.

Throughout history, there have been numerous examples of countries disintegrating or parts of them seceding, such as the "velvet divorce" of Czechoslovakia in 1993, the violent breakup of Yugoslavia, and the independence of South Sudan in 2011. The effects of such ruptures on international treaty relations are well covered in international legal scholarship. ${ }^{2}$ Moreover, in the realm of international organizations, there are examples of members

* Assistant Professor of Comparative, EU and International Law, Leiden University. The author would like to express his gratitude for helpful discussions and comments on drafts of this Essay from the audiences at the 2019 ASIL Research Forum at Brooklyn Law School and the ASIL International Economic Law Interest Group Biennial Conference at the University of Miami School of Law.

${ }^{1}$ Agreement on the Withdrawal of the United Kingdom of Great Britain and Northern Ireland from the European Union and the European Atomic Energy Community, Brussels and London, January 24, 2020, 2020 OJ (L 29) 7 [hereinafter Withdrawal Agreement].

${ }^{2}$ See Gerhard Hafner \& Gregor Novak, State Succession in Respect of Treaties, in The Oxford GUIDE TO Treaties 396 (Duncan B. Hollis ed., 2012). The Vienna Convention on Succession of States in Respect of Treaties, Aug. 23, 1978, 1946 UNTS 3, has been in force since 1996, although it only has twenty-three parties. It contains rules regarding "the replacement of one State by another in the responsibility for the international relations of territory.” Id. Art. 2, para. 1(b). 
withdrawing and organizations disappearing, such as Germany's withdrawal from the League of Nations in 1933, that same organization's dissolution in 1946, and more recently the withdrawal of the Philippines from the Rome Statute establishing the International Criminal Court. Such instances are addressed in international legal rules and scholarship as well. ${ }^{3}$

Brexit, however, falls in between these two categories. It concerns leaving an entity that is "more than an international organization . . . but less than a federal state," ${ }^{4}$ or, stated differently, "a supranational institution that in some ways resembles a nation." 5 Withdrawing from the EU, crucially, is far from a purely intra-European affair. Brexit raises questions about the applicability of hundreds of international agreements to the $\mathrm{UK},{ }^{6}$ for which there are no ready-made answers in international treaty law and with which scholarship has only started to grapple. ${ }^{7}$

Meanwhile, even when the UK was still an EU member state, Brexit had prompted a global recalibration of treaty relations. ${ }^{8}$ This effort is highly charged politically. The vision of an unleashed "Global Britain," which boldly sets out to strike trade deals around the world, has long been a prominent argument of the proponents of leaving the EU.?

\footnotetext{
${ }^{3}$ The Vienna Convention on the Law of Treaties, May 23, 1969, 1155 UNTS 331 [hereinafter VCLT] applies to constituent instruments of international organizations (Art. 5) and contains rules regarding the termination and suspension of treaties (Arts. 54-64), as does the Vienna Convention on the Law of Treaties Between States and International Organizations or Between International Organizations, Vienna, March 21, 1986 [not in force; hereinafter VCLTIO] in its Articles 54-63. See further Henry G. Schermers \& Niels M. BlokKer, International Institutional LaW: Unity Within Diversity 106-34 (6th ed. 2018) (on the termination of membership and dissolution of international organizations); Laurence Helfer, Exiting Treaties, 91 VA. L. Rev. 1579, 1582-86 (2005) (summarizing the different motivations states may have for withdrawing from international organizations); and earlier, Michael Akehurst, Withdrawal from International Organisations, 32 Current Legal Probs. 143 (1979).

${ }^{4}$ Catherine Barnard, Introduction: The Constitutional Treaty, the Constitutional Debate and the Constitutional Process, in The Fundamentals of EU Law Revisited: Assessing the Impact of the Constitutional Debate 1, 3 (Catherine Barnard ed., 2007)

${ }^{5}$ Curtis A. Bradley, What Is Foreign Relations Law?, in The Oxford Handbook of Comparative Foreign Relations Law 3, 3 (Curtis A. Bradley ed., 2019); see also Allan Rosas \& Lorna Armati, EU Constitutional Law: An Introduction 14-19 (3d ed. 2018) (summarizing the EU's state-like and nonstate-like features).

${ }^{6}$ Paul McClean, After Brexit: The UKWill Need to Renegotiate at Least 759 Treaties, FIn. TIMES (May 30, 2017), at https://www.ft.com/content/f1435a8e-372b-11e7-bce4-9023f8c0fd2e.

7 See Adam Łazowski \& Ramses A. Wessel, The External Dimension of Withdrawal from the European Union, Revue des AfFaires européEnNes 623 (2016); Jed Odermatt, Brexit and International Law: Disentangling Legal Orders, 31 Emory InT'L L. Rev. 1051 (2017); Lorand Bartels, The UK's Status in the WTO Post-Brexit, in THE United Kingdom and the Federal Idea 227 (Robert Schütze \& Stephen Tierney eds., 2018); Ramses A. Wessel, Consequences of Brexit for International Agreements Concluded by the EU and Its Member States, 55 COMMON Mкт. L. Rev. 101, 124 (2018); Joris Larik, The New Transatlantic Trigonometry: "Brexit" and Europe's Treaty Relations with the United States, 40 U. PA. J. INT'L L. 1 (2018); Siri Silvereke, Withdrawal from the EU and Bilateral Free Trade Agreements: Being Divorced Is Worse?, 15 InT'L Orgs. L. REv. 321, 339 (2018).

${ }^{8}$ Richard Partington, Brexit: UK Has Rolled Over Just £16bn Out of £117bn Trade Deals, GuARDIAN (Feb. 13, 2019), at https:/www.theguardian.com/business/2019/feb/13/brexit-uk-trade-deals-eu.

9 See UK Prime Minister's Office Press Release, Boris Johnson's First Speech as Prime Minister (July 24, 2019), at https://www.gov.uk/government/speeches/boris-johnsons-first-speech-as-prime-minister-24-july-2019 (including a call to "let's start now on those free trade deals" and calling "to recover [the UK's] natural and historic role as an enterprising, outward-looking and truly global Britain"); Daniel Hannan, Brexit Gives Us the Chance to Trade with New and Old Friends, Starting with Japan, TelEgRAPH (Nov. 30, 2019), at https://www.telegraph.co.uk/ politics/2019/11/30/brexit-gives-us-chance-trade-new-old-friends-starting-japan; TIM OlIVER, UNDERSTANDING Brexit: A Concise InTroduction 67 (2018) ("Vote Leave initially focused on the economic and sovereignty arguments, not least the ability of a non-EU UK to negotiate its own trade deals," noting that later immigration also assumed an important role in the campaign to leave.).
} 
This Essay traces the emerging treaty-making practice surrounding the UK's withdrawal from the EU. It shows that due to the Withdrawal Agreement and its transition period, the UK is experiencing a gradual increase in its treaty-making powers that corresponds to a phased decrease of the constraints that EU (external relations) law imposes on it. The practice to date reveals that Brexit has spawned the creation of a significant amount of new international legal materials, which provide the first contours of how the UK, the EU, and treaty partners around the world answer the novel questions raised for the law of treaties prompted by a nation's withdrawal from a supranational entity that is also an "active treaty-maker."10

Part I provides a brief overview of the background and context of Brexit and its international dimension. Part II elaborates on the shifting legal constraints during the different phases of the UK's withdrawal, as well as the practice to date. Part III concludes.

\section{Brexit and Its International Dimension}

When documenting the story of Brexit from the point of view of international treaty law, two dimensions and their interrelationship need to be taken into account. First is the intraEuropean perspective-that is, the UK's difficult relationship with the EU and the negotiations between the UK and EU on the terms of an orderly withdrawal and their future relationship. Second is the global perspective- that is, the effect of Brexit on the international legal relations of the UK with the rest of the world. To provide the necessary context, this section briefly recapitulates the developments leading up to "Brexit" and introduces its international legal ramifications.

\section{The Brexit Process: "Climbing a Mountain"}

The UK had been a member of the EU and its predecessor organizations since $1973 .{ }^{11} \mathrm{~A}$ mere two years after the country's accession to the then European Economic Community (EEC), a referendum about continuing its membership took place. Margaret Thatcher, at the time the leader of the Conservative Party, passionately and successfully pleaded for the UK to remain. ${ }^{12}$

Since that time, however, the country's relationship with the EEC and later the EU has become increasingly fraught, leading to the UK being described as the EU's most "awkward"13 and "reluctant" 14 member state. The unease started in the mid-1980s with demands for "rebates" and "opt-outs" from various EU policies, including the common currency, the

\footnotetext{
${ }^{10}$ Joris Larik, Instruments of EU External Action, in EU External Relations Law: TeXt, CAses and Materials 101, 109 (Ramses A. Wessel \& Joris Larik eds., 2020).

${ }^{11}$ Treaty Concerning the Accession of the Kingdom of Denmark, Ireland, the Kingdom of Norway and the United Kingdom of Great Britain and Northern Ireland to the European Economic Community and to the European Atomic Energy Community, Brussels, January 22, 1972, 1972 OJ (L 73) 5 (note that Norway, following a referendum rejecting EEC membership, ultimately did not join).

${ }^{12}$ See, e.g., Margaret Thatcher, Speech to Conservative Group for Europe (Opening Conservative Referendum Campaign), Apr. 16, 1975, available at https://www.margaretthatcher.org/document/102675 (noting that leaving the EEC "would be bad for Britain, bad for our relations with the rest of the world and bad for any future treaty on trade we may need to make").

${ }^{13}$ Stephen George, An AwKward Partner: Britain in the European Community (3rd ed. 1998); Oliver, supra note 9, at 39-44.

${ }^{14}$ Finn Laursen, Hans Mouritzen \& Anders Wivel, The Institutional Dynamics of Euro-Atlantic Integration, in The Geopolitics of Euro-Atlantic Integration 39, 44 (Hans Mouritzen \& Anders Wivel eds., 2005).
} 
Schengen zone of passport-free travel, and parts of the police and judicial cooperation in criminal matters. Despite receiving these special privileges and exceptions, ${ }^{15}$ Eurosceptic sentiment in the UK continued to be strong. ${ }^{16}$

A more immediate prelude to Brexit occurred in 2013 when, based on an election pledge of the Conservative Party, Prime Minister David Cameron promised an "in/out referendum" that was to follow a renegotiation of the UK's status within the EU. ${ }^{17}$ The additional concessions he obtained from the EU, ${ }^{18}$ however, failed to convince a majority in the referendum held on June 23, 2016, in which 51.9 percent voted for the UK to leave. ${ }^{19}$

The official process of withdrawal began on March 29, 2017, when Sir Tim Barrow, the UK's permanent representative to the EU, delivered the official notification indicating his country's intention to withdraw from the bloc, as required by Article 50, paragraph 2 of the Treaty on European Union (TEU). ${ }^{20}$ While at first glance Article 50 TEU may appear as a regular treaty termination clause, the UK Supreme Court in the Miller case pointed out the extraordinary nature of commencing the withdrawal process. Leaving the EU amounted to disconnecting the UK from the EU's integrated legal order, with wide-ranging effects on individual rights. Therefore, unlike in the case with other treaties, the UK government needed parliamentary approval before it could trigger TEU Article 50. ${ }^{21}$ The notification set a clock in motion, according to which the terms of the withdrawal should have been finalized within two years, i.e., before March 29, 2019, unless both sides agreed to extend that deadline. ${ }^{22}$

What followed was a series of negotiations marked by tedium, acrimony, and setbacks. ${ }^{23}$ In the somewhat euphemistic words of the EU's chief negotiator Michel Barnier, Brexit was "like climbing a mountain." 24 The negotiators adopted a draft withdrawal agreement and a political declaration on the future relationship in November $2018 .{ }^{25}$ This deal, however, was repeatedly rejected by the UK House of Commons. ${ }^{26}$ As a consequence, the Brexit deadline was extended three times by common agreement between the EU and UK. Boris

15 See David Gowland, Britain and the European Union 219-30 (2016).

16 See The UK Challenge to Europeanization: The Persistence of British Euroscepticism (Karine Tournier-Sol \& Chris Gifford eds., 2015).

${ }^{17}$ Kenneth Armstrong, Brexit Time: Leaving the EU - Why, How and When? 42 (2017).

${ }^{18}$ A New Settlement for the United Kingdom Within the European Union, Extract of the Conclusions of the European Council of 18-19 February 2016, 2016 OJ (C 69I) 1.

${ }^{19}$ UK Electoral Commission, Results and turnout at the EU referendum (last updated September 25, 2019), at https://www.electoralcommission.org.uk/who-we-are-and-what-we-do/elections-and-referendums/past-elections-and-referendums/eu-referendum/results-and-turnout-eu-referendum.

${ }^{20}$ Consolidated Version of the Treaty on European Union, 2016 OJ (C 202) 13, Art. 50, para. 2 [hereinafter TEU]; see in detail on the process, Paul Craig, The Process: Brexit and the Anatomy of Article 50, in THE LAW \& Politics of Brexit 49 (Federico Fabbrini ed., 2017).

${ }^{21} \mathrm{R}$ (on the Application of Miller and Another) (Respondents) v. Secretary of State for Exiting the European Union (Appellant), [2017] UKSC 5, para. 101.

22 TEU, supra note 20, Art. 50, para. 3.

${ }^{23}$ Kevin O'Rourke, A Short History of Brexit: From Brentry to Backstop, ch. 11 (2019).

${ }^{24}$ Barnier: Brexit Deal Negotiations Like Climbing a Mountain, BBC News (Oct. 11, 2019), at https://www.bbc. com/news/uk-politics-50007206.

25 Agreement on the Withdrawal of the United Kingdom of Great Britain and Northern Ireland from the European Union and the European Atomic Energy Community, 2019 OJ (C 144I) 1.

${ }^{26}$ Max Colchester \& Jason Douglas, May's Brexit Deal Is Rejected for a Third Time by Lawmakers, WALL ST. J. (Mar. 29, 2019), at https://www.wsj.com/articles/mays-brexit-deal-is-rejected-for-a-third-time-by-lawmakers11553870628. 
Johnson, a prominent campaigner for Brexit, succeeded Theresa May as prime minister of the UK and continued the negotiations. On October 17, 2019, he reached a revised withdrawal agreement with the EU. Following a general election in the UK held in December 2019, in which the Conservative Party secured a large majority, the agreement was passed by the House of Commons. ${ }^{27}$ It took effect on February 1, 2020 (Brussels time). ${ }^{28}$

The new deal contains a revised Protocol on Northern Ireland, ${ }^{29}$ which, given its troubled history and land border with the Republic of Ireland, was arguably "the biggest stumbling block" 30 in the earlier negotiations. The revised deal emphasizes that "Northern Ireland is part of the customs territory of the United Kingdom." ${ }^{31}$ At the same time, crucially, many EU regulations will be applied and enforced there in practice. ${ }^{32}$ Northern Ireland will be subject to a dual customs regime, in which the EU customs tariff will be applied to goods from the UK or other non-EU countries that are "at risk" 33 of being exported to Ireland or other EU member states. Unlike most of the provisions of the Withdrawal Agreement, this arrangement will persist beyond the end of the transition period. However, a majority of the Northern Ireland Assembly in Stormont can decide to end this arrangement once four years have passed after the end of the transition. ${ }^{34}$ Subsequently, it can decide to end the arrangement every four years thereafter, or eight years in the event that such a vote receives "cross-community support" from unionist and nationalist parties in the Assembly. 35

\section{The International Legal Ramifications of Brexit}

Despite much of the focus in political discourse and media on the UK-EU relationship, the UK's withdrawal from the EU has significant consequences on the international stage as well. ${ }^{36}$ One central question concerns the continued applicability to the UK of the EU's numerous international agreements. The UK's status in more than 750 treaties (as estimated by the Financial Times in May 2017) is in doubt, unless the UK and 168 different third countries negotiate to continue the agreements. ${ }^{37}$

At the start of the official withdrawal negotiations, the European Council posited that the UK would "no longer be covered by agreements concluded by the Union or by member states acting on its behalf or by both acting jointly." 38 This was not contested by the UK

\footnotetext{
${ }^{27}$ Heather Stewart, Brexit: MPs Pass Withdrawal Agreement Bill by 124 Majority, GuARDIAN (Dec. 20, 2019), at https:/www.theguardian.com/politics/2019/dec/20/brexit-pm-asks-britons-to-move-on-as-mps-debate-withdrawal-bill.

${ }^{28}$ European Council Decision (EU) 2019/1810 Taken in Agreement with the United Kingdom of 29 October 2019 Extending the Period Under Article 50(3) TEU, 2019 OJ (L 278I) 1, Art. 1.

${ }^{29}$ Revised Protocol on Ireland and Northern Ireland Included in the Withdrawal Agreement, Oct. 17, 2019, TF50 64 (2019) - Commission to EU 27 [hereinafter Northern Ireland Protocol].

${ }^{30}$ Jennifer Rankin, Why Ireland Is Biggest Stumbling Block in Reaching a Brexit Deal, GUARDIAN (Sept. 17, 2018), at https://www.theguardian.com/politics/2018/sep/17/brexit-why-ireland-biggest-stumbling-block-deal.

${ }^{31}$ Northern Ireland Protocol, supra note 29, Art. 4, para. 1.

${ }^{32}$ Id. Art. 5, para. 4, Annex 2.

33 Id. Art. 5, para. 1.

${ }^{34}$ Id. Art. 18, para. 5.

${ }^{35}$ Id. Art. 18, paras. 5-6.

36 See Łazowski \& Wessel, supra note 7.

${ }^{37}$ McClean, supra note 6.

${ }^{38}$ European Council, Draft Guidelines Following the United Kingdom's Notification Under Article 50 TEU, para. 13, XT 21001 (Mar. 31, 2017).
} 
government, which noted in an October 2017 policy paper that as "we prepare to leave the EU, we will seek to transition all existing EU trade agreements and other EU preferential arrangements." ${ }^{39}$ If EU trade and other agreements with third countries had been considered to continue to apply to the UK, there would have been no need to seek transitional arrangements.

Scholars did not dispute that international agreements concluded by the EU alone-without the member states alongside it - would no longer apply to the UK post-Brexit. ${ }^{40}$ However, a more complex question arose regarding the UK's future status in so-called "mixed agreements" - that is, agreements concluded between the EU and its member states on one side, and one or more third parties, on the other. ${ }^{41}$ While mixed agreements are a hallmark of EU external relations practice, analogue examples in the context of federal states are rare. ${ }^{42}$ Among the EU's mixed agreements, one needs to distinguish, moreover, between bilateral and multilateral agreements - that is, agreements with either one or several external parties.

Examples for multilateral mixed agreements include the United Nations Convention on the Law of the Sea (UNCLOS) and the World Trade Organization (WTO) Agreements. The UK's continued adherence to these agreements was affirmed in the literature, ${ }^{43}$ and has subsequently been confirmed by practice. For example, the UK is still represented at the WTO post-Brexit, but merely informed the membership of its changed status. ${ }^{44}$

By contrast, the UK's continued party status in bilateral mixed agreements was initially more contested. As Siri Silvereke rightly points out, while "these agreements mostly contain provisions related to termination, they do not include any specific clause in relation to a Member State's withdrawal" from the EU. ${ }^{45}$ A number of scholars have argued against their continued applicability because the UK's status in these agreements was premised on being an EU member state. ${ }^{46}$ Without further amendment by common "agreement between the parties" 47 to "trilateralize" these treaties, the UK would no longer be represented in them. The fact that the UK has launched diplomatic efforts striving for "continuity agreements" to replace the EU's trade agreements with external partners (see Part II infra), including mixed

${ }^{39}$ UK Department for International Trade, Preparing for Our Future UK Trade, Cm 9470, 27 (Oct. 2017).

${ }^{40}$ Silvereke, supra note 7, at 339; Odermatt, supra note 7, at 1056.

41 Joni Heliskoski, Mixed Agreements as a Technique for Organizing the International Relations of the European Community and Its Member States 7 (2001).

${ }^{42}$ Robert Schütze, Federalism and Foreign Affairs: Mixity as an (Inter)national Phenomenon, in MixeD Agreements Revisited: The EU and Its Member States in the World 57, 71-72 (Christophe Hillion \& Panos Koutrakos eds., 2010) (using Belgium as an example of a federation that concluded mixed agreements with other countries).

${ }^{43}$ Bartels, supra note 7, at 229-32; Wessel, supra note 7, at 124.

${ }^{44}$ See UK Government, Communication to WTO Members Following the UK's Withdrawal from the EU, pt. 1.1 (Feb. 1, 20) ("The United Kingdom has been, and will continue to be, a Member of the World Trade Organization and will represent its interests and uphold its obligations on that basis from that date.").

45 Silvereke, supra note 7 , at 340 .

${ }^{46}$ Wessel, supra note 7, at 120; Odermatt, supra note 7, at 1059-60; Giorgio Sacerdoti, The Prospects: The UK Trade Regime with the EU and the World: Options and Constraints Post-Brexit, in THE LAW \& POLITICS OF BREXIT 71, 82 (Federico Fabbrini ed., 2017).

${ }^{47}$ VCLT, supra note 3, Art. 39; VCLTIO, supra note 3, Art. 39. The rules regarding the amendment of multilateral treaties between all or some of its parties are not applicable here since these mixed agreements are in essence bilateral. Only through amendment would they be turned into multilateral ones. 
ones, ${ }^{48}$ suggests that the British government concurs that these would no longer apply to the UK post-Brexit.

In addition to the question of finding substitutes for existing agreements concluded by the $\mathrm{EU}$, there is the issue of the British government's plans to conclude new international agreements. Foremost among those are trade agreements with countries with which the EU has not yet concluded a trade deal of its own. The freedom to strike such deals featured prominently in Brexiteers' vision of a "Global Britain" as the UK's post-Brexit foreign policy.

The premise of this idea is that accession to the EU was " $[\mathrm{f}]$ ar from joining an economic powerhouse." ${ }^{49}$ Instead, according to the Brexiteers, the UK had "shackled [itself] to a corpse." 50 It was argued that the EU was sluggish and did not defend British interests in international trade negotiations. In the words of David Davis, published a few months before becoming the UK's first secretary of state for exiting the European Union, "trade agreements negotiated by the EU take a very long time to conclude" and British "interests are not well represented." 51

Once outside the EU, it was argued, the country would thrive, especially in its relations with the wider world. This vision has been aptly summarized by Conservative politician Jacob Rees-Mogg, leader of the House of Commons, on the day the revised Withdrawal Agreement was announced:

We will be able to implement our own free trade deals. We will be able to set our own regulations. We will be in charge of our own laws.... [I]t will be a golden age for the United Kingdom when we are free of the heavy yoke of the European Union, which has bowed us down for generations and made us less competitive, less efficient and higher-cost. ${ }^{52}$

In this endeavor, the UK would be able to draw on its "soft power" and historical ties, such as the Commonwealth ${ }^{53}$ and the "special relationship" with the United States. ${ }^{54}$

48 This is the case, for example, with the trade agreement with the Republic of Korea. The Free Trade Agreement Between the European Union and Its Member States, of the One Part, and the Republic of Korea, of the Other Part, 2011 OJ (L 127) 6, is a mixed agreement that includes the EU member states as parties. The UK has signed a continuity agreement with that country to replace this agreement in June 2019. See Julia Kollewe, UK and South Korea Agree to Sign Post-Brexit Trade Deal, GuARDiAn (June 10, 2019), at https://www.theguardian. com/business/2019/jun/10/uk-south-korea-brexit-trade-deal-asia-eu.

${ }^{49}$ Rowena Mason, Britain "Shackled to Corpse" of EU, Says Douglas Carswell, Telegraph (Oct. 26, 2012), at https://www.telegraph.co.uk/news/politics/9636417/Britain-shackled-to-corpse-of-EU-says-Douglas-Carswell. html.

${ }^{50} \mathrm{Id}$.

${ }^{51}$ David Davis, Britain Would Be Better Off Out of the EU - and Here's Why, ConservativeHome (Feb. 4 , 2016), at https://www.conservativehome.com/platform/2016/02/david-davis-britain-would-be-better-off-outof-the-eu-and-heres-why.html.

${ }^{52}$ UK House of Commons, Hansard, Business of the House (Saturday 19 October), Vol. 666, col. 490 (Oct. 17, 2019), at https://hansard.parliament.uk/Commons/2019-10-17/debates/C7D5E220-3549-4DF1-AF9E07079573464C/BusinessOfTheHouse(Saturday19October).

${ }^{53}$ UK Department for International Trade, supra note 39, at 26 ("The Commonwealth is home to a third of the world's population, many of its fastest growing economies, and half of the globe's top 20 emerging cities. This vast network of growing markets, with which the UK has long-established relationships, presents a significant opportunity for UK business and enhances the UK's ability to promote free trade in a multilateral rules-based system.").

${ }^{54}$ See, e.g., Benjamin Oreskes \& Victoria Guida, The Bright Side of Brexit? A U.S.-UK Trade Deal, Politico (June 24, 2016), at https://www.politico.com/story/2016/06/brexit-us-britain-trade-deal-224776. 
This view is, unsurprisingly, not shared by the EU and proponents for European integration and cooperation. According to the EU, the main rationale for collective action is its ability to extract better terms in treaty negotiations with external partners due to a favorable economic power differential. The European Commission stressed the importance of collective strength through its internal market in its 2015 Trade for All strategy:

The EU is the world's largest exporter and importer of goods and services taken together, the largest foreign direct investor and the most important destination for foreign direct investment (FDI). This scale makes the EU the largest trading partner of about 80 countries and the second most important partner for another 40. The EU should use this strength to benefit both its own citizens and those in other parts of the world, particularly those in the world's poorest countries. ${ }^{55}$

Guy Verhofstadt, the European Parliament's Brexit coordinator, opined that the Brexiteers "drag their country down a path strewn with uprooted trade ties and substantial new barriers to commerce." 56 In his critique of "Global Britain," he observed furthermore that the EU had managed to bring its considerable market power to fruition:

The real global trading power, of course, is the EU, which has recently concluded trade deals with Japan, South Korea and Canada. As an EU member state, the UK automatically benefits from the 40 trade agreements the bloc has in place with more than 70 countries. $^{57}$

Which of these opposing positions will prove to be more accurate may only become clear in the years to come. However, even before the legal constraints applicable to the UK had started to be lifted, the struggle to replace agreements concluded by the EU and explore new ones with partners around the world had already begun.

\section{The Three Phases of the UK's Treaty (Re-)negotiations}

Thanks to the successful ratification of the Withdrawal Agreement, instead of a sudden shift regarding the agreements that had been applicable to the UK, there is a transition period, which gives the UK additional time to find solutions to continuity issues and to start negotiations on new international agreements that do not aim to replace those concluded by the EU. At the same time, the considerable legal constraints under which the UK found itself as a member state have been extended as well. Therefore, the emerging practice of the UK in terms of replacing existing treaties and exploring new treaties is framed by a gradual increase in the UK's international treaty-making powers combined with continuing obligations toward the EU.

Three periods must be distinguished here, given the different legal frameworks that apply to the UK's treaty-making powers: first, the period following the Brexit referendum and prior to the UK's withdrawal; second, the transition period as defined by the Withdrawal Agreement; and third, the time after the end of the transition period.

\footnotetext{
55 European Commission, Trade for All: Towards a More Responsible Trade and Investment Policy 7 (2015).

${ }^{56}$ Guy Verhofstadt, Boris Johnson's Talk of "Global Britain" Is About to Look Even More Ridiculous, GUARDIAN (June 27, 2019), at https://www.theguardian.com/commentisfree/2019/jun/27/boris-johnson-global-britain-eutrade-deal.

${ }^{57} \mathrm{Id}$.
} 


\section{Prior to Leaving the EU}

Following the referendum of June 23, 2016 and before the UK left the EU on February 1, 2020 (Brussels time), the country was still an EU member state with all the rights and obligations that this status entails. The Court of Justice of the EU (CJEU) confirmed this in its Wightman decision, in which it ruled that the UK could unilaterally rescind its intention to withdraw from the EU before the Brexit deadline. Such a revocation would "confirm the EU membership of the Member State concerned under terms that are unchanged as regards its status as a Member State." 58

While still a member state, the UK had to respect the powers that had been conferred upon the EU and the legislation and other rules adopted by the EU, and it also had a more general "duty of sincere cooperation," which is comparable to loyalty principles in federal states-for example, Bundestreue in German constitutional law. ${ }^{59}$ These legal obligations place considerable constraints on the international legal actions of the member states, including on their ability to negotiate and conclude international agreements. ${ }^{60}$

Regarding conferred powers, the member states have lost the power to negotiate their own agreements with external partners in areas where the EU wields "exclusive competence."61 These include the EU's trade policy (known as the "Common Commercial Policy"). ${ }^{62}$ Moreover, in areas where the EU has adopted "common rules," the member states are preempted from taking any action on the international stage which would affect these rules. ${ }^{63}$

In some areas, such as environmental policy, nondirect investments (including investorstate dispute settlement), civil aviation, and security and defense, the member states retain powers of their own. Nonetheless, by virtue of the duty of sincere cooperation, the member states have to "refrain from any measure which could jeopardise the attainment of the Union's objective." ${ }^{44}$ As clarified by the CJEU, this includes a duty not to undermine the EU's internally agreed-upon international negotiation strategy, even in areas of shared powers. ${ }^{65}$ Therefore, negotiating trade and many other types of agreements with third countries while still being a member state is a violation of EU law.

\footnotetext{
${ }^{58}$ Case C-621/18, Wightman v. Secretary of State for Exiting the European Union, ECLI:EU:C:2018:999, para. 74 .

${ }^{59}$ Dirk Hanschel, Konfliktlösung im BundesstaAt 76-79 (2012).

60 See Robert Schütze, Foreign Affairs Federalism in the European Union, in The Oxford HandBooK OF Comparative Foreign Relations LaW, supra note 5, at 333.

${ }^{61}$ Consolidated Version of the Treaty on the Functioning of the European Union, 2016 OJ (C 202) 1, Art. 3, para. 1 [hereinafter TFEU].

${ }^{62}$ Id. Art. 3, para. 1(e).

63 The principle of preemption was first established in Case 22/70 Commission v. Council (ERTA) [1971] ECR 263 and later largely codified in TFEU, Art. 3, para. 2: "The Union shall also have exclusive competence for the conclusion of an international agreement . . . in so far as its conclusion may affect common rules or alter their scope."

${ }^{64}$ TEU, supra note 20, Art. 4, para 3(3).

65 See, in particular, Case C-246/07 Commission v. Sweden (PFOS), ECLI:EU:C:2010:203, para. 91, in which the Court found that "the Kingdom of Sweden [had] dissociated itself from a concerted common strategy within the Council" with regard to an international environmental agreement and had, therefore, violated its duty of cooperation. See Peter van Elsuwege, The Duty of Sincere Cooperation and Its Implications for Autonomous Member State Action in the Field of External Relations, in Between Compliance and Particularism: Member State Interests and European Union Law 283 (Marton Varju ed., 2019); Andrés Delgado Casteleiro \& Joris Larik, The Duty to Remain Silent: Limitless Loyalty in EU External Relations?, 36 Eur. L. REV. 522 (2011).
} 
There are some indications that the UK had been conducting such negotiations already well before its actual exit from the bloc. As early as July 2017, the UK and U.S. governments had launched a "UK-US Trade and Investment Working Group." 66 Moreover, the UK government had started to lay the groundwork continuity solutions for trade agreements concluded by the EU. Instead of "negotiations," 67 the UK government has referred rather to "preliminary discussions" 68 and "preliminary trade deals," 69 possibly in an effort to avoid the impression of a conflict with EU (external relations) law. However, as soon as the preliminary discussions conducted by the UK with countries with which the EU either already has agreements in place, or with which it is in the process of negotiating agreements, "reach a minimum threshold of specificity and could be detrimental to the EU's own position,"70 the UK's engagement with these same countries could amount to a violation of the duty of sincere cooperation based on CJEU case law.

In the area of trade specifically, the UK was at risk of falling out of about forty agreements with roughly seventy countries (and the Palestinian Authority) that the EU has concluded or provisionally applies. These cover approximately 11 percent of the UK's global trade. ${ }^{71}$ As of January 31, 2020, the last day of the UK's EU membership, the UK government had signed twenty trade continuity agreements covering fifty countries or territories, covering "just over $8 \%$ of total UK trade." 72 In some cases, the UK conducted negotiations with these third countries in groups. ${ }^{73}$ In addition, the UK has signed mutual recognition agreements with the United States, New Zealand, and Australia. ${ }^{74}$ It had not yet signed any new trade agreements - that is, agreements that did not replace preexisting ones concluded by the EU.

\footnotetext{
${ }^{66}$ UK Department for International Trade Press Release, US-UK Trade Working Group Lays Groundwork for Potential Future Trade Agreement (July 25, 2017), at https:/www.gov.uk/government/news/us-uk-trade-working-group-lays-groundwork-for-potential-future-free-trade-agreement.

67 While the VCLT and VCLTIO do not contain a definition of "negotiations," Valerio De Oliveira Mazzuoli, The Law of Treaties: A Comprehensive Study of the 1969 Vienna Convention and Beyond 89 (2016) concludes that negotiations for the purposes of the law of treaties have started "when the representatives of States meet at a specific place and at arranged time, for the purpose of studying the possibilities to reach an agreement in connection with the conclusion of a specific international instrument in a joint manner."

${ }^{68}$ Theresa May: UK Will Lead World in Free Trade, BBC News (Sept. 7, 2016), at http://www.bbc.com/news/ uk-politics-37291832.

${ }^{69}$ Kollewe, supra note 48.

${ }^{70}$ Joris Larik, Sincere Cooperation in the Common Commercial Policy: Lisbon, a "Joined-Up" Union, and "Brexit," 8 EuR. Y.B. INT'L ECON. L. 83, 103 (2017); Wessel, supra note 7, at 112.

${ }^{71}$ UK Department for International Trade Press Release, UK Trade with Trade Agreement Continuity (TAC) Countries: Statistical Ad Hoc Release (Updated Dec. 4, 2019), at https://www.gov.uk/government/publications/ uk-trade-agreement-continuity-statistics-and-analysis/uk-trade-with-trade-agreement-continuity-tac-countriesstatistical-ad-hoc-release. Note that this "excludes Turkey, San Marino and Andorra, which are part of a customs union with the EU, and excludes Japan, as the economic partnership agreement only came into force on 1 February 2019." See also Tom Edington, Brexit: What Trade Deals Has the UK Done so Far?, BBC News (Mar. 2, 2020), at https://www.bbc.com/news/uk-47213842.

72 Edington, supra note 71.

73 These are the Andean countries, the CARIFORUM trade bloc, the Central America group, the Eastern and Southern Africa (ESA) trade bloc, Iceland and Norway, the Pacific states group, and the Southern Africa Customs Union and Mozambique (SACU+M) trade bloc.

${ }^{74}$ UK Department for International Trade Press Release, Existing UK Trade Agreements with Non-EU Countries (Jan. 29, 2020), at https://www.gov.uk/guidance/uk-trade-agreements-with-non-eu-countries.
} 
The UK's continuity agreements specify that they will only enter into force when the respective agreement concluded by the EU "ceases to apply to the United Kingdom." 75 This means that they would have become effective immediately following a "no deal" Brexit-in other words, if the UK and EU had failed to conclude the Withdrawal Agreement as a means to extend the application of these agreements to the UK. With the Withdrawal Agreement now in force, the continuity agreements will become effective at the end of a transition period, provided (as discussed below) that third countries agree that a transition as provided in an EU-UK Withdrawal agreement has such an effect.

In terms of format, two different approaches used by the UK can be distinguished. On the one hand, there are the so-called "short form" agreements ${ }^{76}$ that make reference to the content of the corresponding agreement concluded by the EU and then only elaborate on how the short form instrument is to be applied in relation to the UK and the third country, including certain modifications. The text of the EU agreement is thus "incorporated into and made part of" 77 the new UK short form agreement. This approach has been employed, for instance, with regard to Chile and Israel. ${ }^{78}$ On the other hand, there is the option of "long form" agreements, which reproduce the content of the EU-agreement as much as possible. This approach has been applied, for instance, to the agreements with South Korea and the Southern and Eastern African states. ${ }^{79}$

In terms of their respective material contents, both the short form and long form agreements are similar in that they largely carry over the terms of existing agreements between the EU and third countries into a relationship involving the post-Brexit UK. The only difference is the manner in which this is formally represented. Taking the UK-Chile short form agreement as an example, it only consists of ten articles in the main agreement, which are focused for the most part on technical issues such as "definitions," "territorial scope," "amendments," and "entry into force and provisional application." In addition, an Annex lists various specific adaptations to the incorporated agreements that are necessary to reflect its new nature

${ }^{75}$ Free Trade Agreement Between the United Kingdom of Great Britain and Northern Ireland and the Republic of Korea (with Exchange of Notes), Art. 15.10, para. 1, London, Aug. 22, 2019 (not currently in force); Agreement Establishing an Association Between the United Kingdom of Great Britain and Northern Ireland and the Republic of Chile, Art. 10, para. 3(a)(i), Santiago, Jan. 30, 2019. An exception to this pattern is the UK's agreement with Norway and Iceland regarding trade in goods, which would only have entered into force if the UK had withdrawn from the EU "without any agreement between the United Kingdom and the European Union on the terms of the United Kingdom's withdrawal” or if the Withdrawal Agreement had not provided "for the continued application to the United Kingdom of the Trade-Related Agreements between the European Union and one or both of Iceland and Norway in respect of trade in goods," Agreement Between the United Kingdom of Great Britain and Northern Ireland, Iceland and the Kingdom of Norway on Trade in Goods, Art. 17, para. 2, London, April 2, 2019 (not in force). The author thanks Holger Hestermeyer for the latter point.

76 UK Department for International Trade Press Release, Continuing the United Kingdom's Trade Relationship with The Faroe Islands 4 (Feb. 2019), available at https://assets.publishing.service.gov.uk/government/uploads/system/uploads/attachment_data/file/777022/continuing-the-uks-trade-relationship-with-thefaroe-islands.pdf.

${ }_{77}$ See, e.g., Agreement Establishing an Association Between the United Kingdom of Great Britain and Northern Ireland and the Republic of Chile, supra note 75, Art. 3, para. 1.

${ }^{78}$ Id.; Trade and Partnership Agreement Between the Government of the United Kingdom of Great Britain and Northern Ireland and the Government of the State of Israel, Tel Aviv, Feb. 18, 2019.

${ }^{79}$ Free Trade Agreement Between the United Kingdom of Great Britain and Northern Ireland and the Republic of Korea, supra note 75; Economic Partnership Agreement Between the Southern African Customs Union Member States and Mozambique, of the One Part, and the United Kingdom of Great Britain and Northern Ireland, of the Other Part, London, Oct. 9, 2019 (not currently in force). 
as a UK-Chile bilateral agreement, ${ }^{80}$ as well as certain derogations from the original content to reflect the UK's economy rather than the EU's market. ${ }^{81}$

In comparison, the long form UK-South Korea Free Trade Agreement is basically a copyand-paste of its EU-South Korea counterpart, both starting with Chapter One on "Objectives and General Definitions," Chapter 2 on "National Treatment and Market Access for Goods," all the way through to Chapter 15 on "Institutional, General and Final Provisions," followed by a matching set of annexes. Nevertheless, the UK-South Korea Agreement still contains numerous references to EU legislation, but clarifies that this is to mean "European Union legislation in force as incorporated or implemented in United Kingdom law on the day after the United Kingdom ceases to be bound by the relevant European Union legislation."82 Due to the Withdrawal Agreement, that moment would (as discussed below) be the end of the transition period.

The fact that the UK not only negotiated but signed specific "continuity agreements" with a number of countries around the world while still being an EU member state strengthens the argument that the UK may have acted in breach of EU law. If this had been any other member state, outside of the context of leaving the EU, there would be no doubt that these actions would be regarded as violations of the EU's exclusive powers in trade matters and the duty of sincere cooperation.

However, as noted by Marise Cremona, the "period between Article 50 [TEU] notification [of March 29, 2017] and withdrawal is more complex" and thus should be regarded as extraordinary. ${ }^{83}$ She argues that "[a]lthough still a Member State and under obligations of cooperation, the procedure for withdrawal will have been set in motion and a withdrawal agreement will be under negotiation." ${ }^{84}$ Hence, the EU and the UK would have to work together to ensure a smooth transition. Similarly, Thomas Streinz contends that the duty of sincere cooperation requires a "cooperative" approach from both the UK and the EU in the specific context of Brexit. ${ }^{85}$

Nevertheless, such cooperation could be regarded as having materialized in the form of the Withdrawal Agreement and its provisions on a transition period, during which the UK is granted the ability to negotiate with third countries. Moreover, the EU could have expressly authorized the UK, by way of exception, to act in areas of EU exclusive competence even while still being a member state. ${ }^{86}$ However, there is no evidence that the UK requested

\footnotetext{
${ }^{80}$ For example, in terms of the institutional framework to be established by the agreement, it is specified that instead of representatives from the EU, the "Association Council shall be composed, on the one hand, of a Secretary of State of the United Kingdom or their representative(s), and, on the other hand, of the Minister of Foreign Affairs of Chile." Agreement Establishing an Association Between the United Kingdom of Great Britain and Northern Ireland and the Republic of Chile, supra note 75, Annex, sec. 1.

${ }^{81}$ Id.; Annex, sec. 5 regarding the UK's tariff elimination schedule, including tariff quotas.

${ }^{82}$ Free Trade Agreement Between the United Kingdom of Great Britain and Northern Ireland and the Republic of Korea, supra note 75, Art. 1.3, para. 2.

${ }^{83}$ Marise Cremona, Negotiating Trade Deals Before Brexit?, Social Europe (July 25, 2016), at https://www. socialeurope.eu/negotiating-trade-deals-brexit.

${ }^{84} \mathrm{Id}$.

85 Thomas Streinz, Cooperative Brexit: Giving Back Control Over Trade Policy,15 InT'L J. Constitutional L. 271 (2017).

86 TFEU, supra note 61, Art. 2, para. 1 ("When the Treaties confer on the Union exclusive competence in a specific area, only the Union may legislate and adopt legally binding acts, the Member States being able to do so themselves only if so empowered by the Union or for the implementation of Union acts" (emphasis added).).
} 
such an authorization prior to its worldwide efforts to negotiate continuity agreements over the past several years.

Under normal circumstances, in such cases the European Commission could take action against a member state in the form of "infringement proceedings" at the CJEU. ${ }^{87}$ The reasons for the Commission's decision not to do so may include the fact that such proceedings would not have been legally effective in a "no deal" scenario and that the CJEU would likely not have handed down its judgment until after the withdrawal had taken place. The Withdrawal Agreement, by contrast, extends the effects of EU law and the jurisdiction of the CJEU. More plausibly, given the political sensitivities surrounding negotiations on withdrawal and on the future relationship, the Commission may have opted to use its discretion not to bring proceedings, regarding it as unwise to aggravate relations through litigation. ${ }^{88}$

Apart from the continuity agreements negotiated thus far, the fate of many other, often technical agreements, remains uncertain. Recalling the Financial Times' estimate of more than 750 agreements which would no longer apply to the UK, the fate of those which have not been "incorporated" or reproduced with third countries in "continuity agreements" remains unclear. These treaties also concern issues such as rules of origins and mutual recognition. ${ }^{89}$ While generally not well known or well-understood by the media and public, these issues "are immensely important for oiling the wheels of trade." 90

In addition, before its exit from the EU, the UK had not succeeded in finalizing "continuity agreements" with important trading partners such as Canada, Japan, and Turkey. ${ }^{91}$ However, due to the transition period and therefore the continued applicability of the EU law, including its international agreements, to the UK, there is no immediate gap as regards the UK's trading relations with the rest of the world.

A "no deal" scenario, by contrast, would have caused a rupture and accompanying legal uncertainty. Using the example of UK-Switzerland relations, if there had been no Withdrawal Agreement and transition period, the EU-Switzerland Agreement on Agriculture would have ceased to apply to the UK, despite the UK's continuity efforts. Whereas the UK-Switzerland Trade Agreement, which was signed to ensure continuity, incorporates the Agriculture Agreement, ${ }^{92}$ it carves out its Annexes 4, 6, 9, and 11, which concern, respectively, plant protection, feedstuffs, seeds, agricultural products and organically produced food, and animal health and zootechnical measures. These annexes "shall not apply, unless otherwise decided by the relevant Joint Committee" envisaged by the

\footnotetext{
87 TFEU, supra note 61, Art. 258.

${ }^{88}$ Nonetheless, the European Commission brought infringement proceedings against the UK on other matters during period of the withdrawal negotiations. See, for example, this application regarding the EU's value added tax directive, Case C-276/19, European Commission v. United Kingdom, Action Brought on April 1, 2019, 2019 OJ (C 206) 35.

${ }^{89}$ Nicolo Tamberi \& L. Alan Winter, The UK's Continuity Trade Agreements: Is the Roll-Over Complete?, UK Trade Pol'y ObServatory (Mar. 29, 2019), at https://blogs.sussex.ac.uk/uktpo/2019/03/29/the-uks-continuitytrade-agreements-is-the-roll-over-complete.

${ }^{90}$ Marise Cremona, UK Trade Policy, in The UK After BreXit: Legal and Policy Challenges 247, 259 (Michael Dougan ed., 2017).

${ }^{91}$ According to the UK government, discussions with these and other countries are ongoing at the time of writing. UK Department for International Trade, supra note 74.

92 Trade Agreement Between the United Kingdom of Great Britain and Northern Ireland and the Swiss Confederation, Art. 1, para. 1(e), Bern, Feb. 11, 2019 (not currently in force).
} 
agreement. ${ }^{93}$ As a consequence, according to the Swiss government, in a "no deal" scenario, Swiss regulations would have to be met, specific certificates would have been required, and "controls could be carried out at the point of entry into the Switzerland-EU common phytosanitary area."94

This example also highlights the regulatory constraints and controls that apply to Switzerland due to its international treaty relations with the EU. Through trade with Switzerland, the UK thus indirectly reencounters EU rules and regulations from which Brexit was supposed to set the country free. Many Swiss regulations are aligned with those of the EU, based on the bilateral EU-Switzerland agreements. This fact, as well as the EU's powers in controlling the regulatory space that extends to Switzerland, becomes even clearer regarding Annex 11 on animal health:

In the event that no agreement is reached between the United Kingdom and the EU, the UK will no longer be part of the same veterinary area as Switzerland and will have thirdcountry status. ... If the UK leaves the EU without a deal, trade in animals and products of animal origin originating in the UK and entering Switzerland . . . may be interrupted until such time as the EU places the UK on its list of third countries. The EU alone can determine how long this interruption will last. Under the Agreement on Agriculture, Switzerland adopts the EU's lists. As soon as the UK is recognised by the EU as a third country, it will again be able to export animals and products of animal origin into the EU and Switzerland, albeit under the EU's import regulations for third countries. ${ }^{95}$

Thanks to the ratification of the Withdrawal Agreement, a "no deal" scenario and its immediate disruptive effects have been avoided. Nevertheless, these contingency plans already reveal some of the difficulties the UK might encounter at the end of the transition period.

\section{During the Transition Period}

The Withdrawal Agreement between the EU and the UK entered into force on February 1, 2020 (Brussels time). Instead of abruptly releasing the UK from the constraints of EU law, it launched a transition period (sometimes referred to as "implementation period" 96 by the UK government) to ensure a smooth and orderly exit from the Union and to provide time for negotiating the future relationship between the EU and the UK. Moreover, the transition is an attempt to provide legal certainty, including as regards the applicability of the EU's international agreements to the UK. The transition period is set to last until December 31, $2020 .{ }^{97}$ It may be extended by mutual agreement once for up to one or two years. ${ }^{98}$

\footnotetext{
93 Id. Art. 2.

${ }^{94}$ Swiss Federal Government, Economic Relations Between Switzerland and the United Kingdom After Brexit (as of 29.03.2019), E-Informationsdossier, 6.

${ }^{95} \mathrm{Id}$. at 8.

${ }^{96}$ UK Department for Exiting the European Union, Implementation Period, fact sheet (2019).

97 Withdrawal Agreement, supra note 1, Art. 126.

${ }^{98}$ Id. Art. 132, para. 1.
} 
The transition period could be seen as the opposite of "taking back control" - the main slogan of the leave campaign. ${ }^{99}$ During the transition, the UK essentially remains to a very large extent bound by EU law and is subject to the jurisdiction of the CJEU. ${ }^{100}$ This means that the European Commission can still bring cases against the UK for infringing its obligations under EU law and that UK courts can still address requests for preliminary rulings to the CJEU. At the same time, the UK will be not represented in the Union's decision-making bodies. ${ }^{101}$ Most importantly, the UK government has no seat or vote in the European Council and Council of the EU, and UK-elected members no longer sit in the European Parliament.

This status of what could be called "obligation without representation" is also reflected in the external relations domain. Article 129 of the Withdrawal Agreement states that, in principle, "during the transition period, the United Kingdom shall be bound by the obligations stemming from the international agreements concluded by the Union, by Member States acting on its behalf, or by the Union and its Member States acting jointly," 102 thus including both EU-only and mixed agreements. The UK's rights under these agreements are not explicitly mentioned. Moreover, the article notes that "[d] uring the transition period, representatives of the United Kingdom shall not participate in the work of any bodies set up by" these international agreements, unless the country "participates in its own right" or is "exceptionally" invited to attend by the EU. ${ }^{103}$

Furthermore, Article 129 of the Withdrawal Agreement includes a reference to "the principle of sincere cooperation," according to which "the United Kingdom shall refrain, during the transition period, from any action or initiative which is likely to be prejudicial to the Union's interest." ${ }^{104}$ With the arbitration mechanism for adjudicating disputes under the Withdrawal Agreement only becoming effective after the end of the transition period, ${ }^{105}$ violations of the duty of sincere cooperation could be brought by the European Commission to the CJEU, which retains jurisdiction over the UK during that period. What relevance the reference to "sincere cooperation" in the Withdrawal Agreement adds to that commitment as set forth in Article 4, paragraph 3 of the TEU, ${ }^{106}$ remains to be seen. The fact that the UK is no longer an EU member state and has lost its decision-making prerogatives post-Brexit may favor an interpretation that the UK now has a less stringent loyalty duty under EU law.

As regards the rights and benefits under the EU's international agreements that the UK would retain during the transition period, Article 129 of the Withdrawal Agreement includes a footnote which states that the EU "will notify the other parties to these agreements that during the transition period the United Kingdom is to be treated as a Member State for

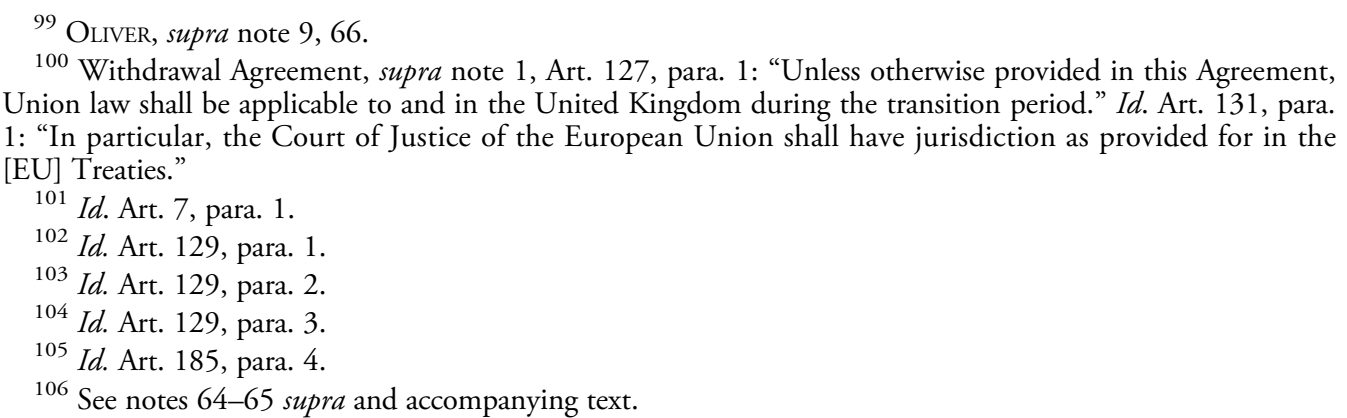


the purposes of these agreements." 107 From the EU's and UK's point of view, the expectation seems to be that for reasons of legal and economic certainty, the external partners will accommodate this request. The continuity agreements the UK has already signed with its external partners, described above, would then only become effective after the end of the transition period.

However, unless one were to consider Brexit a form of secession from a state, ${ }^{108}$ there is no international law obligation to that effect. What the EU and UK decide amongst themselves amounts to res inter alios acta for other states. ${ }^{109}$ Hence, agreements concluded by the EU with third countries cannot continue to be applied to the UK once it ceased to be a member state by virtue of the Withdrawal Agreement alone. Third states could in principle disregard treaty obligations under EU external agreements toward the UK for the simple reason that these exist only toward the EU, or in the case of mixed agreements, the collective of the EU plus its (current) member states.

Third countries are therefore under no duty accommodate the EU's request that the UK "is to be treated as a Member State for the purposes of these agreements." 110 If third countries wanted to cause trouble in this domain, perhaps linked to the pursuit of their interests in other areas or prompted by whichever grievances they may have vis-à-vis the UK, they could refuse to heed the EU's notification during the transition period and treat the UK as a non-EU Member, which it has become on February 1, 2020.

The transition period and the EU's request in the footnote to Article 129 is aimed at providing additional time for the UK to enter into continuity agreements as well as to launch negotiations of new agreements with non-EU partners. In contrast to the pre-Brexit period, such negotiations are now explicitly allowed-though this arguably needs to balance with the above-mentioned "principle of sincere cooperation." The Withdrawal Agreement permits the UK to "negotiate, sign and ratify international agreements entered into in its own capacity in the areas of exclusive competence of the Union, provided those agreements do not enter into force or apply during the transition period, unless so authorised by the Union." 111 As shown in the previous subsection, the continuity agreements signed by the UK pre-Brexit anticipate this scenario, as they will only enter into force once the corresponding agreement concluded by the EU ceases to apply to the UK.

In any event, for external trade partners with which the UK intends to negotiate new agreements, the challenge remains that the UK is yet to clarify its future relationship with the EU, which will commence at the end of the transition period.

\section{After the Transition Period}

According to the Withdrawal Agreement, the transition period is to end either on January 1, 2021, or, if extended, on January 1, 2022 or 2023. From that moment onward, the CJEU

${ }^{107}$ Withdrawal Agreement, supra note 1, Art. 129, para. 1, n. 1.

${ }^{108}$ At least according to the Vienna Convention on Succession of States in respect of Treaties, supra note 2, Art. 34 , para. 1, "[w] hen a part or parts of the territory of a State separate to form one or more States, ... (a) any treaty in force at the date of the succession of States in respect of the entire territory of the predecessor State continues in force in respect of each successor State so formed."

${ }^{109}$ VCLT, supra note 3, Art. 34; VCLTIO, supra note 3, Art. 34.

${ }^{110}$ Withdrawal Agreement, supra note 1, Art. 129, para. 1, n. 1.

${ }^{111}$ Id. Art. 129, para. 4. 
ceases to have jurisdiction in most regards vis-à-vis the UK, with the notable exception being its ability to receive requests for preliminary rulings from UK courts regarding citizens' rights for another eight years. ${ }^{12}$ For disputes regarding the remaining provisions of the Withdrawal Agreement that are still active, an arbitration mechanism will apply to the exclusion of any other means of dispute settlement. ${ }^{13}$ In case the two sides cannot reach a mutually agreed solution, either side may request the establishment of a panel to resolve the dispute. ${ }^{114}$ However, the CJEU makes an indirect appearance here. Panels are directed to request binding rulings from the CJEU in case of questions "of interpretation of a concept of Union law, a question of interpretation of a provision of Union law referred to in this Agreement or a question of whether the United Kingdom has complied with its obligations under Article 89(2) [regarding CJEU judgments and orders handed down before the end of the transition period]."115

The main purpose of the transition period is to allow the EU and UK time to negotiate the terms of their future relationship. A close future relationship between the EU and UK on the one hand, and the UK's flexibility for concluding new international agreements as "Global Britain," on the other, are inversely related. In other words, the closer the UK aligns itself with the EU-in exchange for privileged access to the EU's internal market - the less room it will have to negotiate with other partners around the world, and vice versa.

The EU and UK negotiators have already started to work out a general direction of the future relationship in the form of a political declaration. In its first published version of November 2018, the declaration did not exclude a rather "soft Brexit." It advocated an economic relationship that would "build and improve on the single [EU-UK] customs territory provided for in the [November 2018 version of the] Withdrawal Agreement which obviates the need for checks on rules of origin."116

This language is absent from the revised political declaration of October 2019, due to the replacement of the "all-UK backstop" and its single customs territory encompassing both the EU and the UK with what has been called the Northern Ireland "frontstop"117 in the Withdrawal Agreement. Due to the Northern Ireland Protocol now in force, the frontstop only keeps Northern Ireland de facto in the EU's internal market and customs union, until a majority in the Northern Ireland Assembly in Stormont would decide otherwise. ${ }^{118}$ The revised declaration points instead toward "an ambitious, broad, deep and flexible partnership across trade and economic cooperation with a comprehensive and balanced Free Trade Agreement at its core."119

\footnotetext{
112 Id. Art. 158.

${ }^{113}$ Id. Art. 168.

${ }^{114}$ Id. Art. 170.

${ }^{115}$ Id. Art. 174, para. 1. Such CJEU rulings can also be requested by either party by making submissions to the arbitration panel (Id. Art. 174, para. 2).

${ }^{116}$ Political Declaration Setting Out the Framework for the Future Relationship Between the European Union and the United Kingdom, pt. 23, Nov. 22, 2018, XT 21095/18.

117 Allie Renison, Understanding Brexit: How the "Backstop" Became the "Frontstop," Prospect Mag. (Oct. 18, 2019), at https://www.prospectmagazine.co.uk/economics-and-finance/understanding-brexit-how-the-backstopbecame-the-frontstop-northern-ireland.

${ }^{118}$ See notes 32-35 supra and accompanying text.

${ }^{119}$ Revised Text of The Political Declaration Setting Out the Framework for the Future Relationship Between the European Union and the United Kingdom as Agreed at Negotiators' Level on 17 October 2019, TF5065, pt.
} 3, (2019). 
As of early 2020, the UK government's stance seemed to have hardened even further. A February 2020 white paper stressed that "the UK will fully recover its economic and political independence." ${ }^{120}$ It refuses to "agree to any obligations for our laws to be aligned with the EU's." 121 The goal is now an agreement along the lines of the Comprehensive Economic and Trade Agreement (CETA) Between the EU and Canada. ${ }^{122}$ Failing that, "the trading relationship with the EU will rest on the 2019 Withdrawal Agreement and will look similar to Australia's." 123 The EU and Australia do not have a comprehensive trade agreement, but rely instead on a less ambitious Framework Agreement and a number of treaties of a more technical nature. ${ }^{124}$

The Council of the EU, for its part, has issued negotiating directives that provide an idea of its priorities for the future relationship with the UK. Among other things, the directives stress the need to preserve the integrity of its internal market and to obtain "robust commitments ensuring a level playing field for open and fair competition" from the UK. ${ }^{125}$ To make sure the UK adheres to these commitments, the EU demands "appropriate arrangements for dispute settlement and enforcement." 126 However, this does not amount to insisting on subjecting the UK to the direct jurisdiction of the CJEU. Rather, the EU's negotiating directives envisage arbitration panels similar to the ones of the Withdrawal Agreement, which can refer questions of interpretation of EU law to be ruled upon by the CJEU. ${ }^{127}$

Based on these starting positions, the spectrum of possible, mutually acceptable outcomes seems to have narrowed to somewhat more or less ambitious trade agreements, combined or accompanied with additional agreements on cooperation in other areas such as foreign policy and defense. Such a future relationship between the EU and UK would formally leave the latter free to conclude trade agreements with other countries around the world. CETA includes numerous references to the parties' continued "right to regulate," 128 a concept reiterated also in the revised political declaration. ${ }^{129}$

This also implies the freedom to adapt domestic regulation as a result of trade negotiations with other countries — for example, to accommodate demands from the U.S. government for

${ }^{120}$ HM Government, The Future Relationship with the EU: The UK's Approach to Negotiations, CP 2020, pt. 2 (Feb. 2020).

121 Id. pt. 5.

122 Comprehensive Economic and Trade Agreement (CETA) Between Canada, of the One Part, and the European Union and Its Member States, of the Other Part, 2017 OJ (L 11) (not in force; partial provisional application).

123 Id. pts. 6-7.

${ }^{124}$ Framework Agreement Between the European Union and Its Member States, of the One Part, and Australia, of the Other Part, 2017 OJ (L 237) 7; and, for example, Agreement Between the European Union and Australia Amending the Agreement on Mutual Recognition in Relation to Conformity Assessment, Certificates and Markings Between the European Community and Australia, 2012 OJ (L 359) 2.

${ }^{125}$ Council Decision Authorising the Opening of Negotiations with the United Kingdom of Great Britain and Northern Ireland for a New Partnership Agreement, Addendum: Directives for the Negotiation of a New Partnership with the United Kingdom of Great Britain and Northern Ireland, Feb. 25, 2020, 5870/20 ADD 1 Rev 3, pt. 19.

${ }^{126}$ Id. pt. 158.

127 Id. pt. 160.

${ }^{128}$ Comprehensive Economic and Trade Agreement (CETA), supra note 122, Arts. 8.9, 23.2, 24.3.

${ }^{129}$ Revised Text of the Political Declaration, supra note 119, pt. 18 (stating that the "Parties will retain their autonomy and the ability to regulate economic activity according to the levels of protection each deems appropriate in order to achieve legitimate public policy objectives . .."). 
changes in food standards in favor of American exporters. ${ }^{130}$ Nevertheless, there might be economic constraints that incentivize the UK-its business community in particular ${ }^{131}$ _ to align itself with EU rules so as to maximize access to the EU internal market, which still represents about half of the UK's total trade. ${ }^{132}$

Alternatively, a "no deal" scenario at the end at the end of the transition period-that is, a failure to reach a trade agreement between the EU and the UK-remains a possibility given the relatively short amount of time provided by the transition. ${ }^{133}$ In that case, the UK and EU would fall back on trading under WTO rules. This would significantly limit the UK's access to the EU market, as the EU customs tariff would apply to the UK, which would have no special benefits and advantages. ${ }^{134}$

\section{Conclusion}

On February 1, 2020 (Brussels time), the relationship between the EU and UK irrevocably changed. While the UK's withdrawal has resulted in a significant reduction in population size and economic weight of the bloc, it has spawned a sizeable amount of new international legal materials, including a lengthy Withdrawal Agreement and a series of finalized continuity agreements with countries around the world. Additional continuity treaties, new deals, and an agreement on the future relationship between the EU and UK are in the making. Meanwhile, the EU is not standing still either but is recalibrating its approach to external relations, including by exploring ways to conclude trade agreements in a more streamlined fashion. ${ }^{135}$

Thanks to the Withdrawal Agreement, the ratification of which was uncertain until the final weeks of 2019, there was no rupture either in the legal relations between the EU and UK, or in the UK's treaty relations around the world. Rather, what can be observed is a gradual shift from the UK's status as an EU member state toward its post-Brexit future. Instead of "taking back control" in one abrupt jolt, there are three identifiable stages through which the UK is passing. Each of these stages provides insights into how states (and the EU) deal with the novel questions for the international law of treaties that are raised by the unprecedented event of a state withdrawing from a deeply integrated, supranational organization that is also an avid international treaty-maker.

In the first stage, prior to withdrawal, there were trade continuity negotiations by the UK with external partners while still being a member state, which may have been illegal but were tolerated by the EU. Launching negotiations on continuity agreements revealed that governments did not assume that the rights and obligations under international agreements

${ }^{130}$ Richard Partington, Trump Adviser Ross Says UK-US Trade Deal Will Mean Scrapping EU Rules, GUARDIAN (Nov. 6, 2017), at https:/www.theguardian.com/business/2017/nov/06/trump-ross-says-uk-us-trade-deal-eubrexit-chlorinated-chicken.

${ }^{131}$ Anu Bradford, The Brussels Effect: How the European Union Rules the World (2020).

132 Edington, supra note 71.

${ }^{133}$ Craig, supra note 20, at 69 (noting "the fact that a comprehensive trade agreement will require lengthy discussion”).

${ }^{134}$ Sacerdoti, supra note 46, at 77-78.

135 Joris Larik, EU External Relations Law and Brexit: "When Pluto Was a Planet," 4 Eur. \& World: L. Rev. 1, 12-17 (2020) (summarizing the EU's new practice of splitting up ambitious trade agreements in a way that avoids the need for ratification by the member states). 
concluded by the EU with external partners would devolve onto the UK after it had left the bloc. This even includes bilateral "mixed agreements," to which the UK had been a party in its own right.

The second stage is the "halfway house" of the transition period, during which the EU and UK negotiate their future relationship and during which EU law still largely applies to the UK despite having lost its votes in the bloc's institutions. The Withdrawal Agreement explicitly allows the UK to negotiate continuity and new agreements with other countries during that period, as long as these do not enter into force before the end of the transition and as long as the UK shows a degree of sincere cooperation to the EU. Given that the EU and UK cannot bind third parties through a bilateral agreement between them, including the Withdrawal Agreement, the EU has reached out to external treaty partners, asking them in essence to pretend that the UK was still an EU member state during the transition period for the purposes of treaties concluded by the EU.

The third stage will be the post-transition period, in which the UK's room for maneuver as a global treaty-maker will depend on the shape of its future relationship with the EU. In view of both sides' negotiating positions in early 2020 , a more or less ambitious trade or economic partnership agreement may result. A CETA-style agreement that stresses the parties' "right to regulate" would leave the UK legally free to negotiate different trade agreements with partners around the world under the banner of "Global Britain." However, the extent to which the UK will have the economic clout to disregard the rules set by its largest trading partner remains to be seen, casting doubt on the usefulness of international agreements that ignore economic realities altogether. Nevertheless, with all the uncertainty ahead, one thing is certain: Brexit and its aftermath will produce more, rather than less, international law. 